\title{
O rap como campo de batalha na representação da periferia francesa
}

\section{FELIPE MAIA FERREIRA*}

\section{Resenha de:}

HAMMOU, Karim. Une histoire du rap en France. Éditions La Découverte, 2012, 2014.

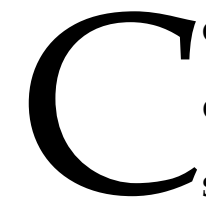

onhecido como o segundo maior mercado produtor de rap, atrás somente dos Estados Unidos, a França é também espaço para trabalhos científicos sobre o gênero desde suas primeiras manifestações no país. Nessa escola, também comparável em profundidade ou mesmo amplitude à produção acadêmica norte-americana - os hip hop studies - , o sociólogo Karim Hammou tem lugar de destaque. Isso se deve a seu extenso trabalho de pesquisa, ainda em curso, que culminou, em 2012, no livro Une Histoire du Rap en France, publicado pela editora La Découverte. Republicada em 2014 em nova edição, a obra se consolida como o guia indispensável para o estudo do rap francês à medida em que seu questionamento mais flagrante passa ao largo da maior parte dos estudos publicados até hoje: por mais atraente que possa soar, a premissa que versa sobre a relação inexorável entre rap e juventude das periferias das grandes cidades não se aplica integralmente ao caso francês. Existe, segundo a tese do autor, um conjunto de variáveis de cunho midiático, econômico e político que articula essa díade em uma rede complexa.

Hammou desconstrói a ideia de que o rap é a voz da periferia na França, como num processo unívoco de fora para o centro de cidades como Paris ou Marselha, ao abrir mão da alegoria dessa população - o jovem marginalizado sob o jugo de preconceitos que protagoniza filmes como La Haine - , sob a qual recai outra via de mão única: o olhar do centro para fora, da biblioteca para a rua, repleto de lugares-comuns e medos associados. Para tal, o autor lança mão de um método

\footnotetext{
* Felipe Maia Ferreira é Bacharel em jornalismo pela Escola de Comunicações e Artes da Universidade de São Paulo. Atualmente, cursa mestrado em música e ciências sociais pela École de Hautes Études en Sciences Sociales. Publicou matérias em diversos veículos da imprensa, tais como Folha de S. Paulo, revista Época, VICE, revista Trip, Makeshift Magazine, Trax Magazine, entre outros. E-mail: felipemf@gmail.com
} 
apurado de análise sociológica sem prestar reverência explícita ao panteão de pesquisadores da disciplina. Fruto de um extenso trabalho de campo, diversas observações e entrevistas com atores fundamentais do movimento compõem o texto; sem limitar-se ao rap, Hammou entende que tal manifestação artística também se cruza com artes visuais e dança - a via pela qual o hip hop chegou à França. Como se propõe histórico, o livro também passa por documentos e informações específicas obtidas em fontes diversas (listas de faixas mais executadas em rádio ou mesmo um fórum de aficionados fazem parte dessa base de dados). Por fim, o pesquisador delimita fatos, ora históricos, ora sociais, que fazem do objeto de sua tese um processo adequado à sua complexidade em que atuam interesses diferentes dentro de um jogo de dominação e representação, como gravadoras no centro dos negócios ou grupos de imigrantes originários das Antilhas ou de países do oeste e norte da África.

De maneira cronológica, Hammou avança em uma história crítica do rap francês em três grandes blocos. Num primeiro tempo ele traz à tona as bases do rap, descrevendo não apenas episódios relevantes, como a breve incursão do gênero na TV em 1984, como também os paradigmas criados por grupos dominantes: a negociação de um vocabulário comum, por exemplo, na qual um campo semântico é formado em prol de uma ideia midiática de uma periferia, isto é, antes que se declare como tal, o rapper é declarado como porta-voz de uma juventude marginalizada, um grupo tido como homogêneo em meio às dez milhões de pessoas que vivem na grande Paris segundo o censo de 2013.

No segundo bloco, Hammou se dedica a entender as relações socioeconômicas que criaram o terreno fértil para a chamada "era de ouro" do rap francês. Segundo o autor, a década de 90 serve ao desenvolvimento de uma rede de atores sociais e práticas culturais que favorecem o crescimento do rap na França: da direção artística de rádios ao viés utilitarista das políticas públicas nacionais, uma vez que o rap se torna via de acesso à periferia. Não à toa, o período conhecido como década de ouro do rap francês viu surgir grupos e artistas lembrados ou ativos até hoje como Suprême NTM, 113, IAM, Doc Gynéco, MC Solaar e Lunatic. 
Por fim, o sociólogo se debruça sobre o campo simbólico que regula o rap nos anos 2000, como numa espécie de exercício de previsão do que viria a partir de então. Fazem parte deste estudo o protagonismo do empresariado e seus escritórios de marketing em busca da figura do superstar, o conflito tenaz entre autenticidade e profissionalização e o êxito do rap no cenário musical francês em meio à derrocada de outros gêneros e sua constante busca por legitimação enquanto parte viva do que se entende por cultura francesa. A análise final de Hammou antecipa o que seria o rap nos anos a seguir: resultado de conflitos em várias esferas, o movimento corresponde atualmente à mais importante manifestação de uma juventude francesa que enxerga a diversidade da sua periferia ou de seu bairro nobre na mesma música. Não é de se espantar que, entre os seis artistas mais ouvidos na França em 2016 pelo serviço de streaming Spotify, cinco sejam rappers franceses que diferem muito em suas propostas dentro do mesmo gênero: Jul, PNL, SCH, Booba e Nekfeu são todos rappers, mas seus projetos se opõem e se cruzam lírica e musicalmente.

Ainda que haja um vasto espectro a explorar dentro dessa realidade que envolve artistas de sucesso, mundo dos negócios e representações várias, Hammou deixa de avançar a uma promissora análise musicológica. Evidentemente isso não parece ser seu objetivo, mas há uma ausência sensível quando ele se limita a falar de "sonoridades" em vez de destrinchar aspectos como métrica, ritmo e harmonias ou abordar questões como hibridismo e autenticidade sem recorrer a estudos feitos nessa área - seria o caso das "músicas jovens", como se refere o musicólogo francês Julien Mallet a algumas categorias de manifestações sonoras urbanas. Por outro lado, o pesquisador corre certos riscos quando avança por searas tangentes à sociologia, como quando descreve a comunicação intermediada pela indústria cultural tal qual um processo vetorial que depende de emissor e receptor - uma ideia que conflita com a superação do estruturalismo proposta ao objeto da tese.

Embora não se oriente por uma análise sociológica hereditária, cujos faróis seriam grandes nomes da escola francesa, Hammou evidencia que seu trabalho reside no jogo de dominação weberiano em um sistema definido. Fora dele, reina a reinvenção de práticas antes calcificadas no mundo da música graças a jovens artistas e meios de produção mais ou menos acessíveis; dentro dele, um processo de 
assimilação que ressignifica um movimento e se apropria do que fora outrora apropriado - o rap como o conhecemos, afinal, ganha forma nos Estados Unidos ao fim da década de 1970. Com isso, Hammou não apenas oferece os guias fundamentais para compreender as representações do rap francês durante a sua curta, porém vasta história, como também desmistifica a sedutora ideia de que rap e periferia são faces de uma mesma moeda. Ao leitor neófito, Une Histoire du Rap en France pode não ser tão palatável como livros que transitam na mesma prateleira, tal qual História Social do Jazz, escrito por Eric Hobsbawm. A obra de Hammou, no entanto, não desliza para o anedotário episódico nem tampouco para análises descoladas das ruas - outro item caro ao ideário do hip hop -, o que lhe confere o primeiro lugar dos incontournables para entender o rap francês.

\section{Referências bibliográficas}

MALLET, Julien. Ethnomusicologie des “jeunes musiques. Em L'Homme 2004/3 ( ${ }^{\circ}$ 171-172), p. 477-488. Paris

LAROCHE, Nadine. La population légale de l'Ile-de-France: 11959807 habitants au 1er janvier 2013. Insee. Disponível em:

<https:// www.insee.fr/fr/statistiques/1895095>. Acesso em: 30 jan. 2017. 